\title{
Exploring the impact of Weblogs as compared to pen-and-paper on Saudi University EFL students' writing: The case of Taif University
}

\section{Dr. Naif Althoabiti *}

\begin{abstract}
Using blogging technology in enhancing language learning has been the concern of many researchers in the last two decades. Specifically, weblogs are claimed to act as a contributing tool to EFL students' language learning and writing. Weblogs can provide students with chances to practice writing in a tension free environment and at their own pace. However, little is known about its feasibility in Saudi EFL writing classes. The study, therefore, attempted to explore the impact of using weblogs, as compared to pen-and-paper, on EFL students' writing in Taif University. The study adopted a mixed design (quantitative and qualitative) to explore EFL students' writings and views about the use of such a technology as compared to pen-and-paper writing. The quantitative part of the study was in the form of quasiexperiment design and the qualitative was in the form of interview. Both methods represent a case study of EFL students in Taif University. A weblog was created for the purpose of the study via the Learning Management System (LMS), Blackboard (BB). The participants were EFL 30 and they were requested to complete pen and paper writing tasks, weblog writing tasks, and the interview. The data were both quantitatively and qualitatively analyzed. The study results showed positive views among students regarding the use of weblogs in their writing class. The results are hoped to provide more insights into and understanding of the link between language learning through writing development and the use of technology in an EFL context. The results are also hoped to serve as starting point for integrating such a technology into language teaching in other university EFL courses. In addition, the study is hoped to provide teachereducators and teachers with insightful recommendations on the development of EFL writing and the use of technology.
\end{abstract}

Keywords: EFL, Saudi Arabia, writing, Weblogs, university students' view, mixed-design, quasiexperimental design.

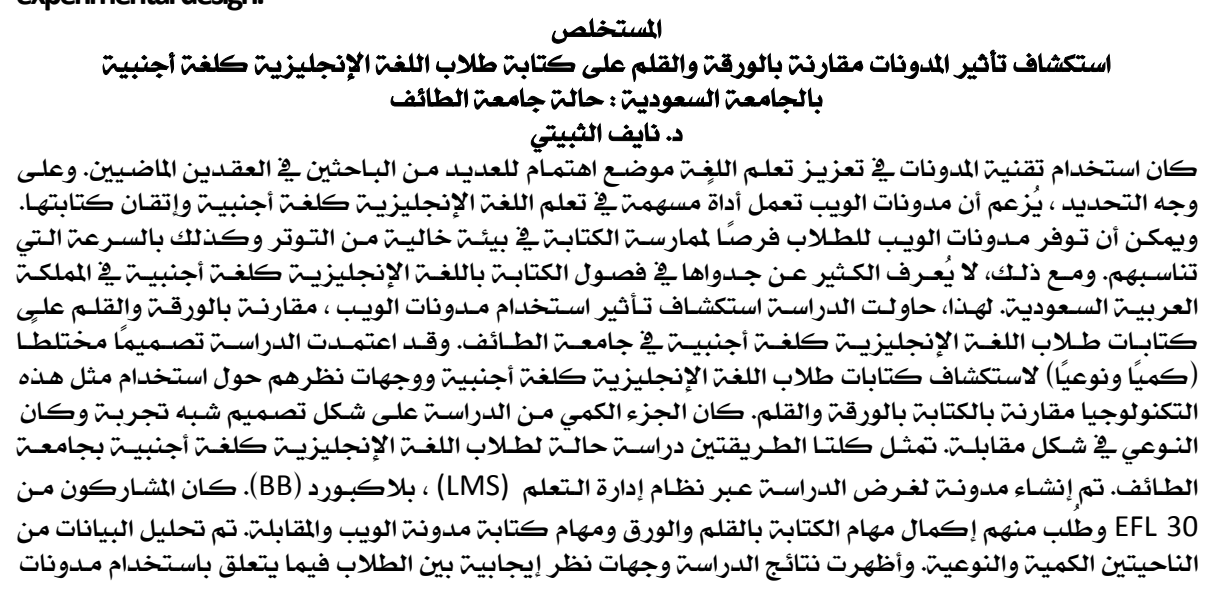

-Department of Foreign Languages - Faculty of Arts - Taif University - Althobaiti@tu.edu.sa 


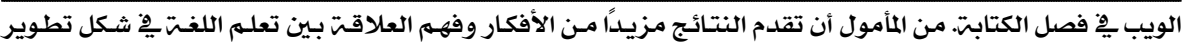

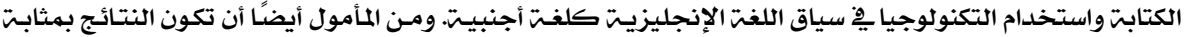

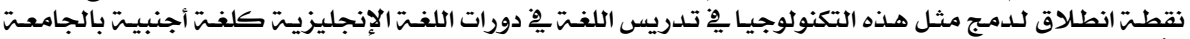

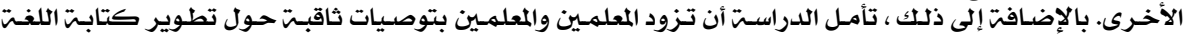

Introduction الإنجليزيت كلغت أجنبيت واستخدام الإنسامل التكنولوجيا.

Writing has been described as an important skill for students to acquire (Althobaiti, 2014). Students around the world should develop a reasonable command of writing skills in order to fulfill the requirements of the courses studied by submitting well written assignments and answering questions in final exams (Al-Khairy, 2013). The case is further evident when investigating the EFL tertiary context. Writing seems to be a crucial medium of communication with teachers in the sense that it shows students' academic progress and knowledge gain (Javid \& Khan, 2014). Furthermore, writing becomes more important in EFL contexts where English is not practiced outside the classroom (Althobaiti \& Algethami, 2018).

However, writing skills in EFL contexts seem to be the most difficult and challenging in that a considerable number of EFL students lack the necessary skills of academic writing (Althobaiti, 2014). They cannot organize their thoughts and ideas in an academic context with which they are not familiar. The reason for this is that the students did not receive enough training on how to write in intermediate and secondary schools, which has made them less proficient writers (Al-Hammadi \& Sidek, 2015). Also, the way they were taught writing focused mostly on grammar and vocabulary and the classes were teacher-dominated; in addition, the students' uppermost concern was how to pass exams (Ezza, 2010; Javid \& Khan, 2014).

Teachers' feedback on students' writing is usually selective for the most frequent errors (Althobaiti, 2014). The reason for this is the large size of classes, which sometimes reach as many as 50 students, a problem which deprives students of detailed feedback on their writing. In addition, such large classes do not permit students to benefit from their peers in the class, as they are totally teacher-dominated (Ezza, 2010). Therefore, it is no wonder that students' writing does not develop to a satisfactory level, and that teachers cannot be of great assistance (Althobaiti, 2014).

Thus, there must be a way to encourage and enhance students' writing as well as to make it interesting and authentic (Althobaiti \& Algethami, 2018). The adoption of technology such as Weblogs may be an option to encourage 
students to improve their writing (Godwin-Jones, 2008). Weblogs can encourage students to write either inside or outside the classroom (Lee, 2010). Also, the integration of Web 2.0 technology such as weblogs is believed to best serve the abovementioned purposes in a way that satisfies students' needs and expectations on the one hand and provides teachers' the capacity for early intervention and correction on the other (Wopereis, Sloep \& Poortman, 2010; Gedera, 2012). It also enables students' peers to read and provide feedback (Gedera, 2012).

Weblogs, which have received considerable attention since 1998, allow people to create, update and publish personal websites ( $\mathrm{Wu}, 2006$ ). Weblogs, as multimedia resources, are one of the few incentives available for teaching and learning (Woo \& Reeves, 2007). Weblogs gained further notice when educators and teachers started to implement them in their reading and writing classes (Wu, 2006). The use of weblogs is considered a facilitating tool for language learning (Fageeh, 2011). Specifically, Weblogs are claimed to enhance students' writing skills, facilitate cooperative interactions, and build their self-confidence (Lee, 2013). Moreover, Weblogs encourage students to write for a larger audience than merely those in the classroom. Students become more attentive to what they write when they account for their audience. They take responsibility for their writing, observe their colleagues' writing, and receive feedback from their colleagues (Lin et al., 2014).

Bearing these points in mind, Saudi EFL tertiary students suffer two main deficiencies: their poor English writing performance and their lack of motivation (Mahmoud, 2014). The implementation of Weblogs in such a context is hoped to contribute to solving these problems. In addition, weblogs have the capacity to provide the space for the students to express themselves and overcome writing blocks in a tension free environment (Lee, 2010). Weblogs can raise students' attention, motivation, and confidence and they can become better writers by acquiring more vocabulary and grammar (Aljumah, 2012).

The learning curve is not as steep people may think; nowadays there are many means available to teachers to enhance and speed up learning (Blood, 2002). Technology 2.0 is characterized by its dynamic nature, socialization, participation, and interaction (Lamb \& Johnson, 2012). With the 
advancement of inclusion technology in education, the employment of Web 2.0 applications and technologies in learning has received gained attention over the past two decade (Richardson, 2005). It has been argued that the employment of Web 2.0 technologies, including Weblogs, has an influence on language learning (Lin et al., 2014). However, the use of such technology and its role in enhancing language learning in specific contexts such as EFL have not received the attention deserved (Lee, 2014). Many authors have pointed to this scarcity of research and called for more empirical evidence in new local contexts such as EFL ones (Lee, 2014; Mahmoud, 2013). The scarcity of evidence is obvious when dealing with tertiary EFL contexts (Aljumah, 2012; Fageeh, 2011). The Saudi context is no exception.

When students use weblogs, they have access to a practical application of their learning. They become more engaged in the process of writing and more responsible and attentive to the writing process (Vurdien, 2013). Also, when students are given the chance to write in weblogs, they are writing for a larger audience, which will result in improvement of their critical thinking skills and cooperative interaction (Halic et al., 2010; Mahmoud, 2014). In addition, teachers in EFL contexts need to allow students to use online weblogs freely in order to reflect on their thoughts and address them in an authentic way to an authentic audience (Lin et al., 2014).

\section{Analogy of Web 1.0 versus Web 2.0 to passive versus active learners}

The change from Web 1.0 to Web 2.0 technology is similar to the transition from the traditional passive learning model to a more active one. As to why Web 2.0 technology is compared to web 1.0, the capacity of each is worth explaining. Web 1.0 is a primary source of information which does not enable users to add materials or respond to the content already posted; they are merely readers and receivers of the knowledge. On the other hand, Web 2.0 technology has the capacity to enable users to read and write at the same time. They can comment, reflect, share ideas, argue, add to the knowledge, and perform many other functions (Lamb \& Johnson, 2012). Likewise, the students in teacher-centered classes are passive receivers of knowledge, while in student-centered classes the learners are more active, engaged, and participating in knowledge making and sharing (Huffman, 2017; Williams \& Chinn, 2009). Oravec (2002) claimed that weblog can "empower students to become more analytical and critical" (p.618). 
Therefore, competent users of technology are able to gain more benefits from adopting technology in their coursework (Venkatesh, Croteau, \& Rabah, 2014). The students become more autonomous and less heavily reliant on teachers and they can select what they want to study (Aşıksoy, 2018). In this way, the use of weblogs suits higher level students simply because lower level students would not be in a position to cope with the level of language skills needed to write, comment, evaluate and share resources in a meaningful way.

It is worth mentioning that teachers should maintain a good grasp of technology knowledge with regard to social media networking (GrayRosendale, 2018). Teachers should be familiar with the possibilities of integrating the different applications to accommodate students' different needs, such as blogs for writing and radios for listening (Althobaiti \& Algethami, 2018). They also need to know the functions of the different platforms that encourage reflection, knowledge creation and sharing (GrayRosendale, 2018).

However, the adoption of weblogs has some pitfalls in the sense that the students may not be competent enough in dealing with such a technology. Also, the students may find it time-consuming to write via weblogs. The students may spend a substantial amount of time in preparing, writing, reading and revising, and publishing. Furthermore, some of the students may not be in favor of using weblogs due to privacy concerns in the sense that they do not want others to know their identifying information. Furthermore, a few studies have been sceptical about the pedagogic value of weblogs, showing that traditional pen-and-paper writing is more favourable (Lin, Groom \& Lin, 2013). Other studies show no significant difference between the two methods, and that research suggests that a balance should be maintained between technology-based writing and paper-based writing (AlKadi \& Madini, 2019).

\section{Significance of the study and research questions}

Although there have been many studies and reviews of the utilization of weblogs as an important educational tool (Lin et al., 2014; Zhang, 2009), more studies are needed; specifically, with regard to the usability of weblogs in foreign languages learning contexts. Many researchers claim that the integration of weblogs in language learning is still in its infancy 
and enough empirical evidence (Hickman, 2011; Lin et al., 2014) has not yet supported the adoption of weblogs in teaching/learning processes. This can be seen in the implementation of weblogs in EFL context where students' English proficiency is low (Mahmoud, 2014).

The studies conducted in Saudi EFL contexts have focused on conceptual aspects, investigating perceptions and attitudes (e.g. Aljumah, 2012) or the utlization of specific Web 2.0 programs such as Facebook (Mahmoud, 2014). They have not investigated the real performance of students. Little attention, if any, has been given to the adoption of weblogs in teaching writing in the Saudi EFL tertiary education context. Thus, this study will bridge this gap in investigation.

The use of weblogs is considered to be an innovative strategy for enhancing students' writing. It is particularly important to use innovative teaching methods in cases where students' language proficiency is low. Thus, more evidence is needed in the form of empirical studies. Researchers have emphasized this by pointing to the scarcity of research in such contexts (Lin et al., 2014).

Weblogs appear to play an important role in enhancing students' writing skills, freeing them from the ties of traditional classrooms and making the physical boundaries of classrooms insignificant. It is expected that this study will help contributing to understand the feasibility of implementing weblogs in EFL writing curricula.

Investigating the students' perceptions as well as production on the adoption on weblogs will help in finding better ways to improve EFL students' writing. This investigation will also provide theoretical and practical recommendations and implications for both teachers and policy makers on the link between the use of computer-mediated communication (CMC) and EFL writing and the usability of weblogs in enhancing EFL students' writing.

It is expected that this exploratory case study of a mixed design will result in a detailed understanding of, and provide more insight into, the usability of Web 2.0 technology (weblogs via BB) as compared to pen-andpaper in relation to the writing of EFL undergraduate students. This study can provide such an understanding by investigating the EFL students' views as well as their writings in a traditional pen-and-paper format and in weblogs. Thus, it is hoped that the study will offer a useful tool for improving EFL 
undergraduate students' writing in the Saudi context. The research questions are:

R.Q.1. What is the effectiveness of pen-and-paper in enhancing EFL Taif University students' writing skills?

R.Q.2. What is the effectiveness of Weblog (BB) in enhancing EFL Taif University students' writing skills?

R.Q.3. What are EFL Taif University students' views regarding the use of penand-paper and weblogs?

\section{Research Objectives}

The current study aimed to achieve these objectives:

- To examine the usability of Weblogs via BB as compared to pen-andpaper in enhancing EFL Taif University students' writing skill; and

- To better understand student's views (preferences and concerns) about the use of Weblogs via BB in EFL writing.

\section{Study hypotheses}

The current study included the following null hypotheses:

1. There are no statistically significant differences at the level (0.05) between the participants' mean scores of in both the pre- and post-tests of writing skills at all its levels and overall scores due to the effectiveness of using pen and paper.

2. The pen-and-paper method achieves a modified gain ratio (on Black's modified Gain Ratio) greater than (1.2).

3. There are no statistically significant differences at the level (0.05) between the participants' mean scores of in both the pre- and post-tests of writing skills at all its levels and overall scores due to the effectiveness of using the blogging strategy.

4. The Weblog via BB achieves a modified gain ratio (on Black's modified Gain Ratio) greater than (1.2).

\section{Methodology}

This part defines the study design, the study setting and participants, the data instruments and procedures, and, finally, the data analysis. The description starts with the context of the study.

\section{Study design}

The current study is designed to obtain a detailed explanation of the phenomenon investigated; therefore, a tool of case study was deemed 
necessary. The case study is thought of as a powerful tool for providing insight into the phenomenon investigated with sufficient breadth and depth (Baxter \& Jack, 2008; Smith, 2015). Such a design provides the researcher with the chance to deeply understand EFL Saudi undergraduates' perceptions of, as well as their writings on, weblogs. The research instrument is discussed in the following section. This approach therefore permits the researcher to explore new understandings of the topic investigated in a way that is not strictly planned in advanced (Smith, 2015).

The current case study of a mixed method design is dependent on two main sources to obtain data: EFL Saudi undergraduate students' actual writings and analysis of the tests (i.e. quantitative; quasi experimental); and interviews (i.e. qualitative). The use of more than one source of data is to triangulate the data collection methodology and in turn ensure the validity and reliability of the study (Östlund et al., 2011).

\section{Study context and participants}

The case study took place at the Foreign Languages department, Taif University in the first semester of 2018. Such a context was considered suitable for the study for two main reasons: the accessibility of the site by the researcher as he is a lecturer there; and the familiarity of the researcher with the writing difficulties faced by students in this context in their naturally occurring context. Furthermore, students' levels of proficiency represented a rich environment for such an experiment. In addition, the students had access to the Blackboard (BB) program in the LMS system, which is provided by the university.

All 30 EFL Saudi undergraduate students in the study were classified as intermediate and enrolled in the third level writing course, for which the prerequisite is the successful completion of two writing courses. Therefore, the students had to have a reasonable proficiency of English. All of them were male and aged from 20 to 22 years, and they shared the same first language which is Arabic.

The students' inclusion in the study was determined by the course they were enrolled in during the first semester of 2018. This sample of students was believed to typify the EFL Saudi undergraduate students in similar programs in Saudi universities. This sample of student participants is expected to provide a deeper understanding of the usability of Web 2.0 
technology (Weblogs via BB) in enhancing EFL students' writing in a tertiary context. The findings of the study might be of benefit to students striving to improve their writing in other similar EFL contexts.

Table 1 shows the relationship between the research questions against the data collection sources.

Table 1. The relationship between the research questions against the data collection sources

\begin{tabular}{|cc|c|}
\hline RQs & Data sources \\
\hline 1- & $\begin{array}{c}\text { What is the effectiveness of pen-and- } \\
\text { paper in enhancing EFL Taif University } \\
\text { students' writing skills? }\end{array}$ & $\begin{array}{c}\text { Pen-and-paper pre-test, treatment and post- } \\
\text { test (quantitative: quasi-experimental) }\end{array}$ \\
\hline $2-$ & $\begin{array}{c}\text { What is the effectiveness of weblog } \\
\text { (BB) in enhancing EFL Taif University } \\
\text { students' writing skills? }\end{array}$ & $\begin{array}{c}\text { Weblogs pre-test, treatment and post-test } \\
\text { (quantitative: quasi-experimental) }\end{array}$ \\
\hline 3- & $\begin{array}{c}\text { What are EFL Taif University students' } \\
\text { views regarding the use of pen-and- } \\
\text { paper and weblogs? }\end{array}$ & Interviews (qualitative) \\
\hline
\end{tabular}

Table 2 shows the stages of data collection chronologically. It also shows the format of the interviews and the writings. As discussed earlier, the study was conducted over eight teaching weeks during the first semester of 2018. There were 30 students involved in the study. Those who missed any one out of the four stages were simply excluded.

Table 2. The stages of data collection and their chronology

\begin{tabular}{|c|c|c|c|c|}
\hline Stages & Data collection & Week & $\begin{array}{c}\text { No. of } \\
\text { students }\end{array}$ & Other specifications \\
\hline Stage 1 & Pre-writing test & 4 & 30 & During class time \\
\hline Stage 2 & Pen-and paper writing treatment & 6 & 30 & During class time \\
\hline Stage 3 & Weblog writing treatment & 6 & 30 & $\begin{array}{c}\text { One week time via } \\
\text { LMS weblogs }\end{array}$ \\
\hline Stage 4 & Post-writing test & 10 & 30 & During class time \\
\hline Stage 5 & Interview & 12 & 30 & During office hours \\
\hline
\end{tabular}

\section{Data collection tools, procedures, and data analysis}

The mixed method dictates the analysis to take two forms; quantitative analysis and qualitative analysis. This section will start with the analysis of writing production and then discusses the interview coding and analysis.

\section{Quantitative Part}

Writing tests: Quasi experiment design, procedures, and analysis This study adopted a quasi-experimental design as follows: 
G OX1O

G OX2 O

Which means:

G: the experimental group consisting of $30 \mathrm{EFL}$ students at Taif University

0 : Writing skill test

X1: First Experimental Treatment (pen and paper)

X2: Second experimental Treatment (Weblogs)

The study's Variables

1. The independent variable is the teaching and it has two levels:

- Pen and paper

- Weblogs via BB

2. The dependent variable is the writing skill.

Having completed the data collection, the researcher conducted data analysis. This is explained in the following section.

Writing skill test

The researcher surveyed the students' opinions about the topics they preferred to write about, and the students' preferences varied; therefore, five topics were chosen in the test construction. This is because being able to choose topics that they are interested in may have a positive impact on students' writing, as well as their ability to write. After determining the topics that students prefer, a test was constructed aiming to find out the extent to which EFL students possess writing skills. So, in order to prepare, control and implement this the test, a list was prepared by means of the following steps:

- Determining the goal of the list. The list aims to identify writing skills needed for English language students at Taif University.

- Generating the content of the list. The content was represented by writing skills that are needed for English language students at Taif University. These skills were taken from previous research and studies that dealt with writing skills, lists, classifications, and analytic scoring rubrics of writing skills. The researcher also sought the opinions of some specialists and experts in the field of EFL writing. Accordingly, nine teacher experts in teaching English to ensure its validity checked the list.

The list included five sub-skills of writing which the researcher chose in a holistic and analytic rubric to check EFL students' writings against. The rubric 
was suggested by Jacobs et al. (1981) and refined by Park (2016) and Wang (2015). The rubric focuses on five writing skills, namely: "content, organization, vocabulary, language use, and mechanics." Content skill concerns the success of the written work. Good writing content refers to the student's ability to make the ideas of the written work relevant and connected to the selected topic, and the rate of this skill is $30 \%$. Organizing skill requires the student to organize the written work, find appropriate expressions and have their ideas organized in a clear, sequential and logical way. The rate of this skill is $20 \%$. Vocabulary selection skill refers to selecting the correct and appropriate vocabulary and using it effectively and appropriately to reach the desired meaning. The rate of this skill is $20 \%$. Language use skill is required to form correct sentences while trying to reduce errors in the use of verbs, word function, pronouns and prepositions. The rate of this skill is $25 \%$. Mechanic skill refers to the students' adherence to the rules of spelling and punctuation while writing. This skill requires the student to avoid spelling errors related to the rules of writing as they result in understanding of the intended meaning. The rate of this skill is $5 \%$.

While the test was initially based on the aforementioned list of writing skills, the preparation of the test went through the following steps:

- Determining the purpose of the test. The test intended to measure the writing skills of English language students at Taif University.

- Formulating the test. The test consisted of five topics. Each student chose the topic about which he preferred to write, with attention paid to writing skills while writing.

- Validity of the test. It was presented to nine referees who were specialists in EFL curricula and methods of teaching. The purpose was to obtain their opinions on the test's suitability and its capacity for measuring writing skills. The test was modified in light of the referees' opinions and suggestions.

- Stability of the test had been calculated by applying it to $14 \mathrm{EFL}$ students at Taif University. They were not included in the study sample. However, they showed similarity to the participants in the study in terms of cultural, social and economic levels. After three weeks, the test was re-applied, and the coefficient (the correlation 
between students' scores in the two applications) was (0.84), showing a high degree of stability.

- The test time was calculated using the following equation: the time taken by the first student to complete + the time of the last student $\div$ 2; the calculated time was (60) minutes.

- By confirming the validity and stability of the test, it was put in its final form.

- Evaluating the test. Both pre- and post-tests were evaluated by adopting the criteria detailed below.

The test's stability confirmed by having an independent teacher evaluate the test. That is, the researcher evaluated the students' answers, and one of the teachers evaluated a copy of the same answers, and the validity of the markers was calculated by using Cooper's equation (number of times of agreement $\div$ number of test questions $\times 100$ ). The compatibility rate reached $81 \%$, which is sufficient for the stability of the evaluation.

\section{Procedures}

After preparing and reviewing the study tool, making the necessary adjustments, and putting it in the final form, the researcher began running the experiment, according to a set of procedures as detailed in the following subsections.

\section{Pre-application procedures}

First, the researcher met the lecturer of the writing subject at the foreign languages department, Taif University to provide him with information about the nature of the study, its objectives, importance, and steps to be followed in teaching writing lessons in the first semester using the pen and paper strategy, and the weblogs strategy. Then, the researcher met the students of the experimental group to explain the nature of the experiment and its purpose, and to reassure them that the goal of the experiment was to help them improve their writing skills. Therefore, the tests that were to be applied would have no effect on their final grades.

\section{Application procedures}

At the time of applying the writing skill test, the researcher supervised the application of the test in cooperation with the course teacher. In addition, the students were asked to fill in the basic information for the test, read the test instructions, answer the questions, and adhere to the 
timeline of the test. Then the researcher calculated the time spent in completing the test. Finally, the test papers were collected.

The researcher started by conducting the pre-test for the pen-andpaper. Students then had comprehensive input (teaching on the pen-andpaper writing skills), after which the post-test for pen-and-paper took place. After the completion of the test, it was evaluated in light of the evaluation rubric prepared for the current study (see Appendix 1), and the results were calculated for each group and prepared for statistical treatment.

The post-test of the pen-and paper strategy was utilized as a pre-test for the second experiment, which was the weblogs one. The students were exposed to a comprehensive input on how to use weblogs in writing. Then, the post-test took place, which was evaluated according to the evaluating rubric adapted for this study. The results were calculated for each group and prepared for statistical treatment.

\section{Procedures after the study experiment}

These included presenting and interpreting the results in light of the theoretical frameworks and previous studies, providing a set of recommendations for future efforts for both researchers and stakeholders.

\section{Qualitative part}

Interviews: design, procedures, data coding and analysis

The interview is considered a powerful tool for obtaining a detailed account of the participants' perceptions and providing the students with the capacity to speak their minds and express their thoughts comprehensively in a stress-free environment (Simons, 2009). In addition, the interview t permits the researcher to obtain more straightforward answers, even when investigating difficult topics (Denscombe, 2010).

The interviews took the form of semi-structured took place after the students finished the writing tests. The interviews were delivered in Arabic. The interview sought information on students' views about traditional writing (pen-and-paper) as compared to writing via weblogs (see Appendix 2).

Students were assured in the consent forms that their identifying information would be confidential and thus their names would be replaced by allocated codes and numbers. The 30 Saudi EFL undergraduates were simply allocated numbers from 1 to represent the first student (S) up to 30 
which it represents the thirtieth student (S). The data sources were coded according to their chronology and the initial letters of the name of the sources. The interview was coded as Int., the pen-and-paper writing was coded as PaP and the weblog was coded as Web. So, if any direct quotes from Saudi EFL undergraduates were inserted as supporting evidence, these were referred to by the source of the data and the number of the student. For example, if the researcher wanted to discuss student 24's response to the interview, then he referenced this as (Int, S24). Additionally, the researcher inserted the page number and line number of the transcript of the interview. The student participants' responses to the interviews were transcribed, typed and saved as Microsoft Word documents. The transcripts of the interviews were subject to careful multiple readings for the purpose of allowing codes and themes to emerge. As a result, the emergent themes were organized in a way that answered the third research question.

For data trustworthiness, some of the participants were requested to go through their pre-interview transcripts and confirm that the transcriptions were exactly what they wanted to say. Additionally, the advice of a critical friend with a relevant PhD was sought through all stages of the study.

\section{Results and discussion}

This section reports on the most significant results in a way that answers the research questions. The section is therefore divided into two main parts according to the research questions and their data sources as shown in Table 1. The first part shows the results of the actual writings of the participants in pre- and post-tests. The second part investigates the participants' perceptions on the importance of the pen-and-paper and weblog via BB writings. The results will be connected to the previous literature where possible.

\section{Quantitative results}

The test of the first hypothesis revealed that there are no statistically significant differences at the level of (0.05) between the mean scores of the students in the pre- and post-application of the writing skill test at all subskills and overall score as a result of the effectiveness of using the pen-andpaper strategy. The means and standard deviations of the students' grades on the pre- and post-tests, and the overall average (means) of their performance on the test as a whole, were extracted. Then a $\mathrm{T}$ test was 
performed to examine the significance of these differences as shown in Table 3.

Table (3): Means, standard deviations, and T-test for students' performance on pen-andpaper test in pre- and post-applications

\begin{tabular}{|c|c|c|c|c|c|c|c|c|}
\hline Writing Sub-skills & application & Mean & $\mathbf{N}$ & $\begin{array}{c}\text { Std. } \\
\text { Deviation }\end{array}$ & $\begin{array}{l}\text { Std. } \\
\text { Error } \\
\text { Mean }\end{array}$ & $T$ & df & Sig \\
\hline \multirow[t]{2}{*}{ Content } & Pre-test & 12.03 & 30 & 3.49 & 0.64 & \multirow[t]{2}{*}{3.44} & \multirow[t]{2}{*}{29} & \multirow[t]{2}{*}{0.002} \\
\hline & Post1 & 13.37 & 30 & 3.73 & 0.68 & & & \\
\hline \multirow[t]{2}{*}{ Organization } & Pre-test & 8.47 & 30 & 2.92 & 0.53 & \multirow[t]{2}{*}{5.52} & \multirow[t]{2}{*}{29} & \multirow[t]{2}{*}{0.000} \\
\hline & Post1 & 9.33 & 30 & 3.10 & 0.56 & & & \\
\hline \multirow[t]{2}{*}{ Vocabulary } & Pre-test & 7.90 & 30 & 2.72 & 0.49 & \multirow[t]{2}{*}{7.41} & \multirow[t]{2}{*}{29} & \multirow[t]{2}{*}{0.000} \\
\hline & Post1 & 9.10 & 30 & 2.76 & 0.50 & & & \\
\hline \multirow[t]{2}{*}{ Language use } & Pre-test & 12.00 & 30 & 4.74 & 0.87 & \multirow[t]{2}{*}{3.81} & \multirow[t]{2}{*}{29} & \multirow[t]{2}{*}{0.001} \\
\hline & Post1 & 13.10 & 30 & 4.02 & 0.74 & & & \\
\hline \multirow[t]{2}{*}{ Mechanics } & Pre-test & 2.23 & 30 & 1.07 & 0.19 & \multirow[t]{2}{*}{2.26} & \multirow[t]{2}{*}{29} & \multirow[t]{2}{*}{0.030} \\
\hline & Post1 & 2.43 & 30 & 1.01 & 0.18 & & & \\
\hline \multirow[t]{2}{*}{ Total } & Pre-test & 42.63 & 30 & 14.44 & 2.64 & \multirow[t]{2}{*}{8.25} & \multirow[t]{2}{*}{29} & \multirow[t]{2}{*}{0.000} \\
\hline & Post1 & 47.33 & 30 & 13.80 & 2.52 & & & \\
\hline
\end{tabular}

It can be seen from Table 3 that the values of $(t)$ are statistically significant at the level ( $\alpha \leq 0.05)$, and accordingly, the null hypotheses are rejected. The alternative hypotheses are accepted, with a statistically significant difference at the level of significance $(\alpha \leq 0.05)$ between the mean scores of the students' grades in the pre- and post- application of writing skill test, attributed to the effectiveness of using pen-and-paper. Figure 1 shows the very small differences between the mean scores of the students' grades in the pre- and post-tests. 


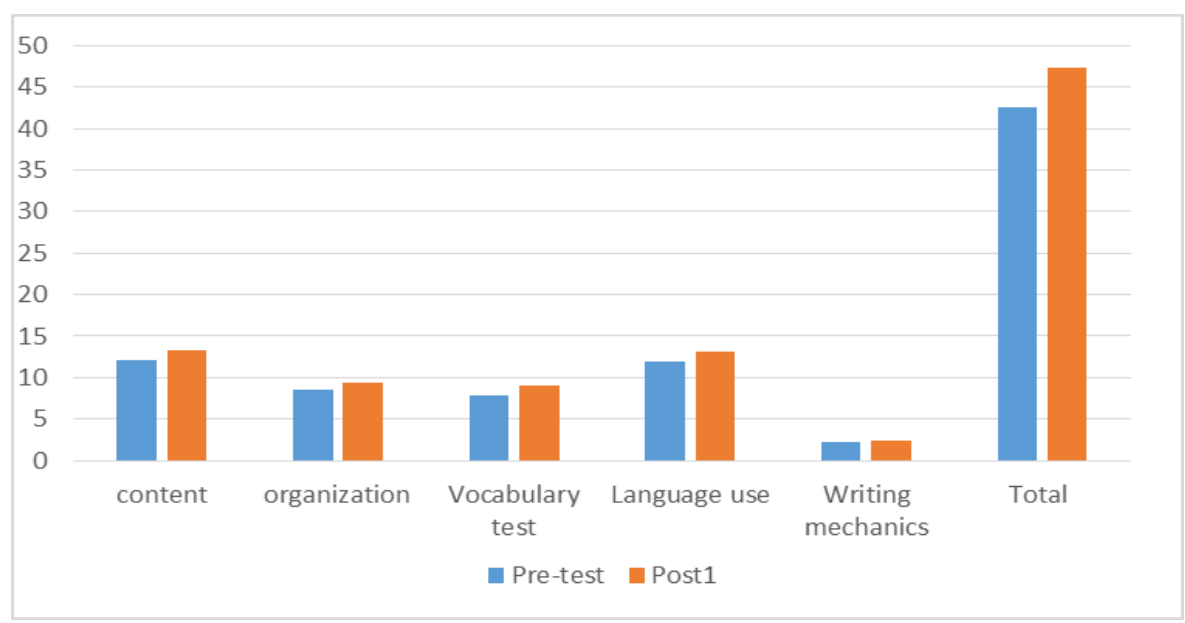

Figure (1): Mean scores of students' performance on the writing skill test in the pre and post application of the pen and paper strategy

To determine the effectiveness of using the pen-and-paper method in improving the students' writing skills, the Black's modified gain ratio was calculated to examine the second hypothesis: the paper-and-pen achieved the Black's modified gain ratio greater than (1.2). Table 2 shows a summary of the modified gain results.

Table (4): Summary of Black's modified gain ratio according to the pen-and-paper

\begin{tabular}{|c|c|c|c|}
\hline Total score (T) & $\begin{array}{c}\text { Pretest mean score } \\
(\mathbf{Y}-\mathbf{X})\end{array}$ & $\begin{array}{c}\text { Posttest mean } \\
\text { scores (T-X) }\end{array}$ & $\begin{array}{c}\text { Black's modified } \\
\text { gain ratio }\end{array}$ \\
\hline 100 & 4.70 & 75.37 & 0.13 \\
\hline
\end{tabular}

It is evident from Table 4 that the pen-and-paper method did not achieve a modified gain ratio greater than (1.2). Therefore, the second hypothesis is rejected, and alternative hypotheses are accepted: The pen and paper strategy did not achieve a modified gain ratio of "Blake" greater than (1.2).

The third hypothesis stated that there are no statistically significant differences at the level of $(0.05)$ between the averages of the study participants' scores in the pre- and post- application to test the writing skill at its levels and overall score due to the effectiveness of using the weblogs via BB. The means and standard deviations of the students' grades on the pre- 
and post-tests, and the overall average (means) of their performance on the test as a whole, were extracted.

Then a $T$ test was performed to examine the significance of these differences as shown in Table 5.

Table (5): Means, standard deviations, and T-test for students' performance on weblogs via BB test in pre- and post-applications

\begin{tabular}{|c|c|c|c|c|c|c|c|}
\hline Writing Sub-skills & Application & Mean & $\mathbf{N}$ & $\begin{array}{c}\text { Std. } \\
\text { Deviation }\end{array}$ & $t$ & df & Sig \\
\hline \multirow[t]{2}{*}{ Content } & Post1 & 13.37 & 30 & 3.74 & \multirow[t]{2}{*}{21.65} & \multirow[t]{2}{*}{29} & \multirow[t]{2}{*}{0.000} \\
\hline & Post2 & 26.67 & 30 & 2.20 & & & \\
\hline \multirow[t]{2}{*}{ Organization } & Post1 & 9.33 & 30 & 3.10 & \multirow[t]{2}{*}{16.50} & \multirow[t]{2}{*}{29} & \multirow[t]{2}{*}{0.000} \\
\hline & Post2 & 17.17 & 30 & 2.09 & & & \\
\hline \multirow[t]{2}{*}{ Vocabulary } & Post1 & 9.10 & 30 & 2.76 & \multirow[t]{2}{*}{25.34} & \multirow[t]{2}{*}{29} & \multirow[t]{2}{*}{0.000} \\
\hline & Post2 & 17.73 & 30 & 2.20 & & & \\
\hline \multirow[t]{2}{*}{ Language use } & Post1 & 13.10 & 30 & 4.02 & \multirow[t]{2}{*}{14.20} & \multirow[t]{2}{*}{29} & \multirow[t]{2}{*}{0.000} \\
\hline & Post2 & 22.60 & 30 & 1.63 & & & \\
\hline \multirow[t]{2}{*}{ Mechanics } & Post1 & 2.43 & 30 & 1.01 & \multirow[t]{2}{*}{12.10} & \multirow[t]{2}{*}{29} & \multirow[t]{2}{*}{0.000} \\
\hline & Post2 & 4.40 & 30 & 0.67 & & & \\
\hline \multirow[t]{2}{*}{ Total } & Post1 & 47.33 & 30 & 13.80 & \multirow[t]{2}{*}{25.22} & \multirow[t]{2}{*}{29} & \multirow[t]{2}{*}{0.000} \\
\hline & Post2 & 88.57 & 30 & 6.00 & & & \\
\hline
\end{tabular}

It is evident from Table 5 that the values of $(t)$ are statistically significant at the level of ( $\alpha \leq 0.05$ ). Accordingly, the null hypotheses are rejected, and alternative hypotheses are accepted, with a statistically significant difference at the level of significance $(\alpha \leq 0.05)$ between the students' mean scores of in the pre- and post-application of the writing skill test, and could be attributed to the effectiveness of using the weblogs via BB. Figure 2 shows the significant differences between the mean scores of the students' grades in the pre- and post-tests. 


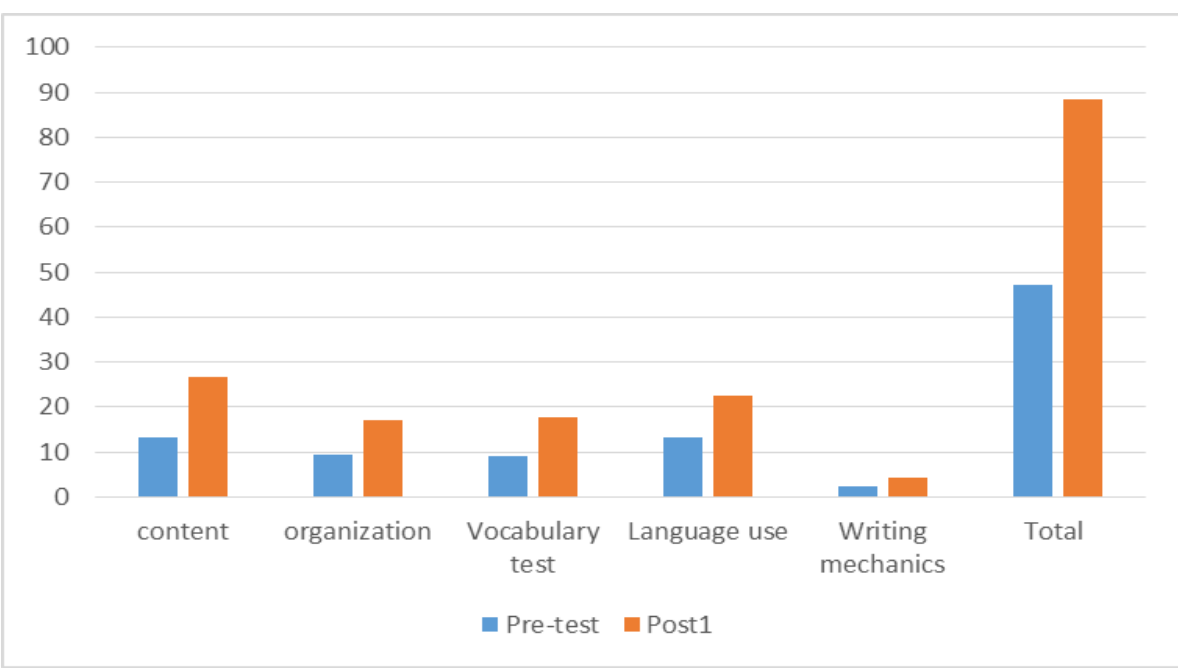

Figure (2): Mean scores of students' performance on the writing skill test in the pre and post application of blogging strategy

To show the effectiveness of using weblogs via BB in improving the students' writing skill, Black's modified gain ratio was calculated to examine the fourth hypothesis that the weblogs via BB achieves the Black's modified gain ratio greater than (1.2). Table 6 shows a summary of the modified gain results.

Table (6): Summary of Black's modified gain ratio according to the weblogs via BB

\begin{tabular}{|c|c|c|c|}
\hline Total score (T) & $\begin{array}{c}\text { Pre-test mean score } \\
(\mathbf{Y}-\mathbf{X})\end{array}$ & $\begin{array}{c}\text { Post-test mean } \\
\text { scores (T-X) }\end{array}$ & $\begin{array}{c}\text { Black's modified } \\
\text { gain ratio }\end{array}$ \\
\hline 100 & 41.24 & 52.67 & 1.21 \\
\hline
\end{tabular}

It is evident from Table 6 that the weblogs via BB did achieve a greater modified gain ratio than (1.2). Therefore, the fourth hypothesis is accepted, which indicates that weblogs via BB have improved students' writings on the post-test, while the pen-and-paper method did not achieve a modified gain ratio greater than (1.2). This in turn shows the superiority of the Weblogs via BB over the pen-and-paper method in terms of improving students' writing skills.

\section{Qualitative results}

The results of the interviews generally revealed a strong preference for writing via weblogs over pen-and paper. This preference is apparent in that most of the responses favoured the use of weblogs via BB in their 
writing. The students reported that the weblogs helped them in many ways; for example, they become more aware of their goals for their writing.

They also stated that the exposure to colleagues' weblogs helped them learn new vocabulary. Other students obtained a great deal of benefit in gaining new vocabulary when they start writing via weblogs. They claimed that the repeated exposure to writing and reading helped them memorise new words and retain them. In addition, they gained self-confidence and became more motivated. However, the improvement in spelling they claimed might be attributed to the spell-check function available in BB. Also, it is worth mentioning that some students reported, that regardless of the benefit they can derive from using $B B$, they preferred to write using pen-andpaper to improve their handwriting, memorise new vocabulary, and have more spelling accuracy. Some responses were miscellaneous, neither supporting pen-and-paper nor rejecting it. This might be resulted from the students' lack of knowledge and their concerns with the teacher-dominated courses.

\section{Summary of results and discussion}

The results showed the positive impact of the integration of weblogs via $\mathrm{BB}$ as compared to pen-and-paper. Both the quantitative and the qualitative data showed the significant impact of weblogs via BB. Thus, in general, the study revealed that weblogs via BB improved students' writing compared to pen-and-paper in many areas: boosting self-confidence, gaining density of vocabulary, and increasing motivation. This is congruent to Vurdien (2013) claim that weblogs have the capacity to provide students with opportunities to express their thoughts easily and foster their writing skills, and to encourage them to write. These characteristics of weblogs are considered to make them a facilitative tool to make students better writers (Sun, 2010). The students also stated that, when they wrote using weblogs, they felt more responsible for their writing so they needed to show their command of language skills. This is similar to Chen and Brown's (2012) argument that weblogs increase students' sense of ownership which in turn urges them to develop their linguistic ability as well as their attitudes towards learning writing. Furthermore, the students reported that the audience they wrote for had helped them to improve their writing. These results align with those of Lin et al. (2014), who stated that teachers need to allow students to 
use online weblogs freely in order to reflect on their thoughts and address them to an authentic audience. Furthermore, one student stated, "I think weblogs have a problem in that they just allow students in the class to read and comment... we need a larger audience" (Int. S11, Line 654). This result supports Campbell's (2004) finding that no outside readers could participate is considered as one of the challenges faced by EFL teachers using weblogs.

However, some students mentioned that they could not cope with writing via weblogs as they needed to be trained more in accurate spelling, and to memorise the new vocabulary. This can be seen in this extract: "I can't imagine that I am going to write with a pen and paper... you know... and the writing through BB needs more effort and time... no benefit at all" (Int. S17, Line 923). This result contradicts many studies that have supported the usefulness of weblogs. However, it is congruent with Lin's (2013) finding that traditional pen-and-paper writing is more favourable.

\section{Study Limitations}

This study has few limitations. The study sample could have been more representative of the Saudi undergraduates in many universities. The sample could also include female students. However, these limitations might be attributed to access and time limitations. In spite of these restrictions, it is expected to provide many valuable insights into EFL writing improvement at the Saudi undergraduate level. It also directs future efforts and paves new avenues for forthcoming studies.

\section{Conclusion and Recommendations for Further Research}

The study aimed to investigate the effect of implementing weblogs via BB on Saudi EFL students' writing. This topic was selected for investigation due to the fact that, in the Saudi tertiary undergraduate context, writing is considered as weakness. As a step toward enhancing this skill, the researcher decided to diagnose the current status of students' writing skills by making a comparison between pen-and-paper writing and weblog writing by means of seeking the students' views as well as reviewing their performance on writing tests. The investigation consisted of two streams. One dealt with writing as the final product by asking students to write in the classroom under the pressure of time and limits to their consultation of dictionaries, while the second dealt with writing as a process in which they were able to have time space as well as access to dictionaries. The study showed that the latter 
helped students in moving from the surface level of writing to a deeper writing process, which focused on the clarity of ideas and structures and the emotional perspective.

The participants, in the weblogs, showed ability to reflect on their experience as well their daily life situations. However, very few were able to reflect on the elements of writing practices. Therefore, future efforts should consider the topics that will spark students' self-reflections. Also, stakeholders should consider integrating technology in teaching writing in a way that encourage EFL students to practice writing in a tension free environment. With more effort and exposure to the language structure and grammar, EFL students are likely to reach a higher level of competency as well as to gain a reasonable command of writing. This will improve their ability to express their views and opinions with confidence.

Future studies should include a larger sample which depicts female students, and they should examine teachers' perspectives. The studies should target teachers' readiness to deal with different forms of technology and see whether or not they will be able to deal with the large volume of students' production via Blackboard. Teachers and stakeholders are advised to train in the use of such tools as weblogs in teaching writing to EFL students.

The researcher would consider the use of Blackboard as an essential element for the improvement of EFL writing. Therefore, the inclusion of BB writing as a part of regular teaching curriculum is recommended. It is the time of technology; there is no reason to stay behind and keep silent. Technology must speak. 


\section{References}

1. Al-Hammadi, F., \& Sidek, H. M. (2015). An analytical framework for analysing secondary EFL writing curriculum: Approaches for writing and preparation for higher education. International Education Studies, 8(1), 59-70.

2. Aljumah, F. H. (2012). Saudi learner perceptions and attitudes towards the use of blogs in teaching English writing course for EFL majors at Qassim University. English Language Teaching, 5(1), pp.100-116.

3. AlKadi, S. Z., \& Madini, A. A. (2019). EFL learners' lexico-grammatical competence in paper-based vs computer-based in genre writing. Arab World English Journal (AWEJ) Special Issue on CALL Number 5, July 2019, Available at SSRN: https://ssrn.com/abstract=3431758 or http://dx.doi.org/10.2139/ssrn.3431758

4. Al-Khairy, M. A. (2013). Saudi English-Major undergraduates' academic writing problems: A Taif University perspective. English Language Teaching, 6(6), p1. http://dx.doi.org/10.5539/elt.v6n6p1

5. Althobaiti, N. \& Algethami, G. (2018). Engaging EFL Saudi tertiary students' writing skills by using Weblogs: Implications to EFL program development. Menoufia University Faculty of Arts Journal, 113 (29),3-16.

6. Althobaiti, N. (2014). Error correction in EFL writing: The case of Saudi Arabia, Taif University. Journal of Modern Education Review, 4(12), 1038-1053.

7. Álvarez, G. (2012). New technologies in the university context: The use of blogs for developing students' reading and writing skills. Universities and Knowledge Society Journal (RUSC), 9(2), pp. 185-199. http://dx.doi.org/10.7238/rusc.v9i2.1160

8. Ananyeva, M. (2014). "Blogfolios" and their role in the development of research projects in an advanced academic literacy class for ESL students. TechTrends, 58(5), 22-26.

9. Arena, C. (2008). Blogging in the language classroom: It does not simply happen. TSEL-EJ. Teaching English as a second or Foreign Language, 1, 4. http://www.teslej.Org/wordpress/past-issues/volume11/ej44/ej44a3/

10. Aşıksoy, G. (2018). The effects of the gamified flipped classroom environment (GFCE) on students' motivation, learning achievements and perception in a physics course. Quality \& Quantity, 52(1), 129-145. 
11. Aydin, S. (2014). The use of blogs in learning English as a Foreign Language. Mevlana International Journal of Education (MIJE), 4(1) ,244-259.

12. Baxter, P., \& Jack, S. (2008). Qualitative case study methodology: Study design and implementation for novice researchers. The Qualitative Report, 13(4), 544-559.

13. Blood, B. (2002). The Weblog Handbook: Practical Advice on Creating and Maintaining your blog. Basic Books.

14. Blood, R. (2002). Weblogs: A history and perspective. In Editors of Perseus Publishing (Eds.). We've Got Blog: How Weblogs are Changing Culture (pp. 7-16). Cambridge, MA: Perseus Publishing.

15. Campbell, A. P. (2004). Using LiveJournal for authentic communication in EFL classes. The Internet TESL Journal, 10(9), 64-68.

16. Chen, J. C., \& Brown, K. L. (2012). The effects of authentic audience on English as a second language (ESL) writers: A task-based, computermediated approach. Computer Assisted Language Learning, 25(5), 435-454.

17. Dalir, M., Jafarigohar, M., \& Soleimani, H. (2013). The effect of using weblogs on Iranian EFL learners' writing skill. International Journal of Language Learning and Applied Linguistics World, 3(4), 213-223.

18. Denscombe, M. (2010). The good research guide for small-scale social research projects (4th ed.). Maidenhead, UK: Open University Press.

19. Dieu, B. (2004). Blogs for language learning. Essential Teacher, Autumn 1(4), 26-30.

20. Ezza, E. S. (2010). Arab EFL learners' writing dilemma at tertiary level. English Language Teaching, 3(4), 33-39.

21. Fageeh, A. I. (2011). EFL learners' use of blogging for developing writing skills and enhancing attitudes towards English learning: An exploratory study. Journal of Language and Literature, 2(1), 3-48.

22. Gedera, D. (2012). The dynamics of blog peer feedback in ESL classroom. Teaching English with technology, 12(4), 16-30.

23. Godwin-Jones, R. (2008). Web-writing 2.0: Enabling, documenting, and assessing writing online. Language Learning \& Technology, 12(2), 7-12.

24. Gray-Rosendale, L. (Ed.). (2018). Getting personal: teaching personal writing in the digital age. Albany, New York: SUNY Press. 
25. Halic, O., Lee, D., Paulus, T., \& Spence, M. (2010). To blog or not to blog: Student perceptions of blog effectiveness for learning in a college-level course. The Internet and Higher Education, 13(4), 206- 213.

26. Huffman, K. L. (2017). Digital art history: Building a "model" for student engagement. In Visualizing Venice (pp. 111-117). Routledge.

27. Jacobs, H.L., Zinkgraf, S.A., Wormuth, D.R., Hartfiel, V.F. and Hughey, J.B. (1981). Testing ESL composition: a practical approach. Rowley, MA: Newbury House.

28. Javid, C. Z., \& Umer, M. (2014). Saudi EFL learners' writing problems: a move towards solution. Proceeding of the Global Summit on Education GSE, 4-5.

29. Johnson, A. (2004). Creating a writing course utilizing class and student blogs. The Internet TESL Journal, 10(8), 10-10.

30. Kim, H. (2008). The phenomenon of blogs and theoretical model of blog use in educationalcontexts. Computers \& Education, 51 (1), 1342-1352.

31. Kress, G. (2005). Gains and losses: New forms of texts, knowledge, and learning. Computers and composition, 22(1), 5-22.

32. Lamb, A., \& Johnson, L. (2012). Technology swarms for digital learners. Teacher Librarian, 39(5), 67.

33. Lee, L. (2010). Fostering reflective writing and interactive exchange through blogging in an advanced language course. ReCALL: the Journal of EUROCALL, 22(2), 212

34. Lee, M. C. (2013). The multifaceted aspects of blogging as an educational platform. In Knowledge Sharing through Technology (pp. 56-68). Springer Berlin: Heidelberg.

35. Liang, M. Y. (2010). Using synchronous online peer response groups in EFL writing: Revision-related discourse. Language Learning \& Technology, 14(1), 45-64.

36. Lin, M. H., N. Groom and C. Y. Lin. (2013). Blog-assisted learning in the ESL writing classroom: A phenomenological analysis. Educational Technology and Society 16(3): 130-139.

37. Lin, M. H., Li, J. J., Hung, P. Y., \& Huang, H. W. (2014). Blogging a journal: Changing students' writing skills and perceptions. ELT Journal, 68(4), 422-431. 
38. Mahmoud, S. S. (2014). Email and Facebook to promote Foundation Year students' EFL writing at King Abdul-Aziz University. International Review of Social Sciences \& Humanities, 6(2), 157-172.

39. Oravec, J. A. (2002). Bookmarking the world: Weblog applications in education. Journal of Adolescent \& Adult Literacy, 45(7), p. 616-621.

40. Östlund, U., Kidd, L., Wengström, Y., \& Rowa-Dewar, N. (2011). Combining qualitative and quantitative research within mixed method research designs: A methodological review. International Journal of Nursing Studies, 48(3), 369-383.

41. Park, J. (2016). Integrating reading and writing through extensive reading. ELT Journal, 70(3), 287-295.

42. Richardson, W. (2005). Blogs, wikis, podcasts, and other powerful web tools for classrooms. Corwin press: Thousand Oaks.

43. Sari, S. D. (2014). The student-bloggers' voices on the contribution of EFL writing through blogging. Beyond Words, 2(1), 90-111.

44. Simons, H. (2009). Case study research in practice. SAGE publications: Thousand Oaks.

45. Smith, J. A. (Ed.). (2015). Qualitative psychology: A practical guide to research methods. Sage: Thousand Oaks.

46. Sullivan, A. (2008). Why I blog. The Atlantic, 11. http://www.theatlantic.com/magazine/archive/2008/11/why-iblog/307060/

47. Sun, Y. C. (2010). Extensive writing in foreign-language classrooms: A blogging approach.Innovations in Education and Teaching International, 47(3), 327-339.

48. Trayek, A., Fuad, A., Hassan, S., \& Sariah, S. (2013). Attitude towards the use of learning management system among university students: A case study. Turkish Online Journal of Distance Education-TOJDE, 14(3), 91103.

49. Venkatesh, V., Croteau, A. M., \& Rabah, J. (2014, January). Perceptions of effectiveness of instructional uses of technology in higher education in an era of Web 2.0. In 2014 47th Hawaii international conference on system sciences (pp. 110-119). IEEE. 
50. Vurdien, R. (2013). Enhancing writing skills through blogging in an advanced English as a Foreign Language class in Spain. Computer Assisted Language Learning, 26(2), 126- 143.

51. Vygotsky, L. S. (1978). Mind in society: The development of higher psychological. Cambridge, MA: Harvard University.

52. Wang, Y. C. (2014). Using wikis to facilitate interaction and collaboration among EFL learners: A social constructivist approach to language teaching. System, 42, 383-390.

53. Warschauer, M. (1996).Comparing face-to-face and electronic discussion in the foreign language classroom. CALICO Journal, 13(2-3), 7-26.

54. Williams, J., \& Chinn, S. J. (2009). Using Web 2.0 to support the active learning experience. Journal of Information Systems Education, 20(2), 165.

55. Woo, Y., \& Reeves, T. C. (2007). Meaningful interaction in web-based learning: A social constructivist interpretation. The Internet and higher education, 10(1), 15-25.

56. Wopereis, I. G., Sloep, P. B., \& Poortman, S. H. (2010). Weblogs as instruments for reflection on action in teacher education. Interactive Learning Environments, 18(3), 245-261.

57. Wu, W. S. (2006). The effect of blog peer review and teacher feedback on the revisions of EFL writers. Journal of Education and Foreign Languages and Literature, 3(2), 125-138.

58. Ying, K. K., Cheung, M., Leung, K., Kwan, R., Lee, R., \& Wong, K. (2013). Learning through blogging: Understanding teacher and student perceptions towards English writing blogs. In Knowledge Sharing through Technology (pp. 200-211). Springer Berlin: Heidelberg.

59. Yu-Chun Wang (2015). Promoting collaborative writing through wikis: a new approach for advancing innovative and active learning in an ESP context. Computer Assisted Language Learning, 28:6, 499-512.

60. Zhang, D. (2009). The application of blog in English writing. Journal of Cambridge Studies, 64, 64-73. 
Appendix 1: Table Evaluating Rubric

\begin{tabular}{|c|c|c|c|c|c|c|}
\hline & Weight & Excellent & Good & Developing & Inadequate & Weak/Poor \\
\hline Content & $30 \%$ & $\begin{array}{c}27-30 \\
\text { Comprehensive } \\
\text { coverage of topic. } \\
\text { Knowledeagability } \\
\text { Relevance to the } \\
\text { topic. } \\
\text { Objectivity. }\end{array}$ & \begin{tabular}{|c|}
$22-26$ \\
Sufficient \\
coverage of topic. \\
Lacking \\
necessary details.
\end{tabular} & \begin{tabular}{|c|}
$17-22$ \\
Limited \\
information. \\
Lacking many \\
details. \\
Less objectivity.
\end{tabular} & $\begin{array}{c}\quad 13-16 \\
\text { Insufficient } \\
\text { information. } \\
\text { Some relevance of } \\
\text { the details shown } \\
\text { to the topics. }\end{array}$ & \begin{tabular}{|c|}
$0-12$ \\
No information or \\
irrelevance of the \\
details to the topic. \\
No objectivity. \\
Simply struggling \\
writer.
\end{tabular} \\
\hline Organization & $20 \%$ & $\begin{array}{c}18-20 \\
\text { Clear, fluent, and } \\
\text { organized ideas }\end{array}$ & \begin{tabular}{|c|}
$14-17$ \\
Most of the main \\
ideas are clear \\
however, not \\
very well \\
connected. \\
\end{tabular} & \begin{tabular}{|c|}
$10-13$ \\
Some of the \\
ideas are clear \\
but with limited \\
connectedness.
\end{tabular} & \begin{tabular}{|c|}
$7-9$ \\
Ideas are not \\
fluent, unclear, \\
and unconnected. \\
Logical sequence \\
is incomplete. \\
\end{tabular} & $\begin{array}{c}0-6 \\
\text { No organization in } \\
\text { the text. No } \\
\text { communication and } \\
\text { flow of ideas. }\end{array}$ \\
\hline Vocabulary & $20 \%$ & $\begin{array}{c}18-20 \\
\text { Appropriate } \\
\text { selection and use of } \\
\text { words. Adequate } \\
\text { and Well- } \\
\text { developed } \\
\text { vocabulary range. }\end{array}$ & \begin{tabular}{|}
$14-17$ \\
Sufficient range \\
of words. Good \\
command of \\
word use with \\
minor errors \\
where meaning \\
is still clear
\end{tabular} & \begin{tabular}{|c|}
$10-13$ \\
Limited words \\
range. Frequent \\
mistakes in \\
words selection \\
and use which \\
may impact the \\
meaning.
\end{tabular} & \begin{tabular}{|c|}
$7-9$ \\
Not enough word \\
range to complete \\
the task. Meaning \\
is mostly \\
ambiguous.
\end{tabular} & \begin{tabular}{|c|}
$0-6$ \\
Translation-driven \\
words. Lack of \\
knowledge \\
demonstrated. \\
Major errors \\
exhibiting \\
understanding \\
of the text. \\
\end{tabular} \\
\hline $\begin{array}{c}\text { Language } \\
\text { Use }\end{array}$ & $25 \%$ & $\begin{array}{c}22-25 \\
\text { Complex syntactic } \\
\text { ability. Very few } \\
\text { errors, if any, in } \\
\text { sentences } \\
\text { structure, } \\
\text { functions, and } \\
\text { meanings. }\end{array}$ & $\begin{array}{c}18-21 \\
\text { Simple yet } \\
\text { effective syntax. } \\
\text { Some errors in } \\
\text { verbs, numbers, } \\
\text { 'word-order/ } \\
\text { function, } \\
\text { pronouns and } \\
\text { prepositions', but } \\
\text { their meaning is } \\
\text { sometimes } \\
\text { ambiguous } \\
\end{array}$ & \begin{tabular}{|c|}
$11-17$ \\
Frequent errors \\
in negation, \\
verbs, numbers, \\
'word-order/ \\
function, \\
pronouns and \\
prepositions'. \\
Meaning of the \\
sentence is \\
sometimes \\
ambiguous.
\end{tabular} & \begin{tabular}{|c|}
$5-10$ \\
Lack of syntactic \\
knowledge. \\
Inability to \\
construct some \\
sentences. Large \\
number of errors. \\
The meaning of \\
sentences is \\
ambiguous.
\end{tabular} & \begin{tabular}{|c|}
$0-4$ \\
No syntactic \\
knowledge. Now \\
awareness of \\
meaning. Inability to \\
write a syntactically \\
correct sentence. \\
Incoherent \\
sentences.
\end{tabular} \\
\hline Mech & $5 \%$ & $\begin{array}{c}5 \\
\text { Very few if any, } \\
\text { errors in spelling } \\
\text { and punctuations. }\end{array}$ & \begin{tabular}{|c|}
4 \\
Some spelling \\
and punctuation \\
errors but not \\
impacting the \\
meaning of the \\
sentences.
\end{tabular} & \begin{tabular}{|c|} 
\\
Frequent errors \\
in spelling and \\
punctuations \\
with some \\
ambiguities.
\end{tabular} & \begin{tabular}{|c|}
2 \\
Large number of \\
errors in spelling \\
and punctuation \\
which imped \\
understanding \\
and create many \\
confusions.
\end{tabular} & \begin{tabular}{|c|}
1 \\
Weak command of \\
spelling and \\
punctuation. \\
Unclear handwriting \\
and construction of \\
sentences.
\end{tabular} \\
\hline
\end{tabular}




\section{Appendix 2}

The 30 EFL Saudi undergraduates were asked to give their opinions on:

Their thoughts about traditional writing (pen-and-paper),

The characteristics this kind of writing exhibited,

Their thoughts about weblog writing,

The characteristics this kind of writing exhibited,

The problems encountered when writing by using pen-and-paper and writing by using weblogs.

The interview questions, the emergent themes, the references, and the codes

\begin{tabular}{|c|c|c|c|c|}
\hline Questions & Theme & References & Description & Codes \\
\hline \multirow[t]{2}{*}{$\begin{array}{c}\text { Students' } \\
\text { preferences }\end{array}$} & \begin{tabular}{|c|} 
Positive \\
view of pen- \\
and-paper
\end{tabular} & $\begin{array}{c}7 \\
(23 \%)\end{array}$ & $\begin{array}{c}\text { The students reported they } \\
\text { experienced improvement in this } \\
\text { way of writing. }\end{array}$ & $\begin{array}{c}\text { General tendency toward using this way by using } \\
\text { words such as "Like, prefer, love, favor, agree, } \\
\text { support and so on." }\end{array}$ \\
\hline & $\begin{array}{l}\text { Positive } \\
\text { view of } \\
\text { weblogs }\end{array}$ & $\begin{array}{c}23 \\
(76.66 \%)\end{array}$ & $\begin{array}{c}\begin{array}{c}\text { It has a positive impact on their } \\
\text { writing and thus they believe } \\
\text { their writing had improved. }\end{array} \\
\end{array}$ & $\begin{array}{c}\text { General tendency toward using this way by using } \\
\text { words such as "Like, prefer, love, favor, agree, } \\
\text { support and so on"” }\end{array}$ \\
\hline \multirow[t]{2}{*}{ Characteristics } & $\begin{array}{l}\text { Pen-and- } \\
\text { paper }\end{array}$ & 3 & $\begin{array}{c}\text { The features or merits the } \\
\text { students have when using this } \\
\text { way. }\end{array}$ & $\begin{array}{l}\text { Helps improve handwriting } \\
\text { Helps in memorizing words } \\
\text { Learn accurate spellings }\end{array}$ \\
\hline & Weblogs & 24 & $\begin{array}{c}\text { The features or merits the } \\
\text { students have when using this } \\
\text { way. }\end{array}$ & $\begin{array}{c}\text { Pressure-free } \\
\text { Peer feedback: comments and likes } \\
\text { Make you read } \\
\text { Motivation as you write for audience } \\
\text { Responsible for learning } \\
\text { Density of vocabulary } \\
\text { No spelling errors } \\
\text { Access to web resources such as Google and } \\
\text { dictionaries } \\
\text { Fluency of ideas }\end{array}$ \\
\hline \multirow[t]{2}{*}{ Problems } & $\begin{array}{c}\text { Pen-and- } \\
\text { paper }\end{array}$ & 26 & $\begin{array}{c}\text { The problems or challenges the } \\
\text { students encountered when } \\
\text { using this way. }\end{array}$ & $\begin{array}{c}\text { Inaccurate and unclear handwriting } \\
\text { Frequent spelling mistakes } \\
\text { Pressure of time } \\
\text { You write for only one reader } \\
\text { Lack of motivation } \\
\text { Controlled sitting either in selecting the topic or } \\
\text { the inability to collaborate with peers }\end{array}$ \\
\hline & Weblogs & 8 & $\begin{array}{c}\text { The problems or challenges the } \\
\text { students encountered when } \\
\text { using this way }\end{array}$ & $\begin{array}{c}\text { Pressure of audience } \\
\text { Embarrassing: fear of being mocked at when } \\
\text { committing errors. } \\
\text { Ethics issues related to plagiarism } \\
\text { More efforts needed: lack of training; slow } \\
\text { writers... } \\
\text { Time-consuming: } \\
\text { ZUnfamiliarity with weblogs }\end{array}$ \\
\hline
\end{tabular}

